\title{
Thermochemical equilibrium study of ash transformation during combustion and gasification of sewage sludge mixtures with agricultural residues with focus on the phosphorus speciation
}

\author{
Thomas Karl Hannl $^{1}$ (D) $\cdot$ Hamid Sefidari $^{1} \cdot$ Matthias Kuba ${ }^{2,3} \cdot$ Nils Skoglund $^{2,3,4} \cdot$ Marcus Öhman $^{1}$
}

Received: 26 March 2020 / Revised: 8 May 2020 / Accepted: 14 May 2020 / Published online: 4 June 2020

(C) The Author(s) 2020

\begin{abstract}
The necessity of recycling anthropogenically used phosphorus to prevent aquatic eutrophication and decrease the economic dependency on mined phosphate ores encouraged recent research to identify potential alternative resource pools. One of these resource pools is the ash derived from the thermochemical conversion of sewage sludge. This ash is rich in phosphorus, although most of it is chemically associated in a way where it is not plant available. The aim of this work was to identify the P recovery potential of ashes from sewage sludge co-conversion processes with two types of agricultural residues, namely wheat straw (rich in $\mathrm{K}$ and $\mathrm{Si}$ ) and sunflower husks (rich in $\mathrm{K}$ ), employing thermodynamic equilibrium calculations. The results indicate that both the melting behavior and the formation of plant available phosphates can be enhanced by using these fuel blends in comparison with pure sewage sludge. This enhanced bioavailability of phosphates was mostly due to the predicted formation of K-bearing phosphates in the mixtures instead of $\mathrm{Ca} / \mathrm{Fe} / \mathrm{Al}$ phosphates in the pure sewage sludge ash. According to the calculations, gasification conditions could increase the degree of slag formation and enhance the volatilization of $\mathrm{K}$ in comparison with combustion conditions. Furthermore, the possibility of precipitating phosphates from ash melts could be shown. It is emphasized that the results of this theoretical study represent an idealized system since in practice, non-equilibrium influences such as kinetic limitations and formation of amorphous structures may be significant. However, applicability of thermodynamic calculations in the prediction of molten and solid phases may still guide experimental research to investigate the actual phosphate formation in the future.
\end{abstract}

Keywords Sewage sludge $\cdot$ Wheat straw $\cdot$ Sunflower husks $\cdot$ Modeling $\cdot$ Phosphorus recovery

\section{Introduction}

Depleting natural resources and the ongoing population growth require major changes in the concepts of resource

Thomas Karl Hannl

thomas.karl.hannl@1tu.se

1 Energy Engineering, Division of Energy Science, Luleå University of Technology, SE-971 87 Luleå, Sweden

2 BEST - Bioenergy and Sustainable Technologies GmbH, Inffeldgasse 21b, AT-8010, Graz, Austria

3 Institute of Chemical, Environmental \& Bioscience Engineering, TU Vienna, AT-1060 Vienna, Austria

4 Department of Applied Physics and Electronics, Umeå University, SE-901 87 Umeå, Sweden consumption and recycling. Phosphorus $(\mathrm{P})$ is one of the resources for which it is crucial to find recycling strategies soon, due to the limited amount of extractable phosphate rock in the earth's crust as well as the irreplaceability of phosphorus in a variety of organisms such as plants and creatures [1]. An increased $\mathrm{P}$ recycling can decrease the societal dependency on mined P minerals and thereby decrease the P losses in the global phosphorus balance. These losses have been identified to be mainly associated with accumulation in soils, landfilling, and transfer of $\mathrm{P}$ into the hydrosphere [2]. Feasible options for minimizing the $\mathrm{P}$ losses include the reduction of fertilizer application, the recovery of $\mathrm{P}$ from P-rich wastes, and the centralized gathering of P-rich residual streams in specific facilities. The present work investigates the potential of $\mathrm{P}$ recovery from the P-rich residual stream of sewage sludge.

Sewage sludge represents a suitable source for $\mathrm{P}$ recovery because of its high $\mathrm{P}$ content. However, its high content of 
potentially environmentally harmful elements and substances $[3,4]$ limits the application of sewage sludge as fertilizer on arable land. A way of separating beneficial from harmful fractions in sewage sludge is combustion and gasification, followed by the use of the sewage sludge ash as fertilizer or fertilizer precursor. Through the thermochemical conversion of sewage sludge, harmful components can be destroyed (e.g., hormones or pathogens) or separated (e.g., heavy metals) from the P-rich coarse ash fraction [5-7].

Sewage sludge ashes contain $\mathrm{P}$ amounts in a similar range as in mined phosphate rocks, i.e., up to $30 \mathrm{wt} \% \mathrm{P}_{2} \mathrm{O}_{5}[8,9]$. Nevertheless, the speciation of $\mathrm{P}$ in the sewage sludge ash tends to display mainly low plant available $\mathrm{Ca}$ phosphates and requires additional preparation before being used as fertilizer [10, 11]. Potential methods to create plant available $P$ compounds from sewage sludge ash are subsequent thermochemical treatment with alkali salts [12] and acidic or basic extraction [10]. Through the addition of alkali salts, the compounds whitlockite $\left(\mathrm{Ca}_{3}\left(\mathrm{PO}_{4}\right)_{2}\right)$ and apatite $\left(\mathrm{Ca}_{5}\left(\mathrm{PO}_{4}\right)_{3} \mathrm{OH}\right)$ in sewage sludge ash from mono-combustion plants, which are poorly plant available, may be transferred into alkali phosphates such as $\mathrm{CaNaPO}_{4}$, which are more readily taken up by plants [12]. The formation of K-bearing phosphates in the coarse ash fraction during combustion processes, where $\mathrm{K}$ and $\mathrm{P}$ are available, was shown previously [13, 14]. Furthermore, a positive effect of $\mathrm{K}$ amendments on the solubility and plant availability of $\mathrm{P}$ in the ashes was found [15].

A possibility of forming plant available $\mathrm{P}$ species directly during the thermochemical conversion is the co-conversion of sewage sludge with alkali-rich fuels, which may produce alkali-containing phosphates $[16,17]$. The incorporation of alkali elements in phosphates formed already in the combustion or gasification process could potentially render additional thermochemical treatments redundant. Such phosphates may provide a possibility to extract fertilizer material directly from the thermochemical conversion process, provided that the previously mentioned separation of heavy metals could be achieved. Co-pyrolysis of sewage sludge with agricultural residues has shown its practical benefits in terms of heavy metal immobilization [18] and char conversion [19]. However, the composition of these fuel blends in the cocombustion systems might hamper the operational performance due to enhanced ash melt formation. The use of such fuel blends in industrial plants should be preceded by a theoretical and experimental analysis of the main benefits and drawbacks, to guarantee process stability and predict the chemical association of $\mathrm{P}$ in the ash fraction.

The objective of this work is to predict the resulting ash composition in combustion and gasification processes using sewage sludge mixtures with agricultural residues, namely, wheat straw (K- and Si-rich) and sunflower husks (K-rich and Si-lean), by thermodynamic equilibrium calculations focusing on the $\mathrm{P}$ speciation. The applicability of employed thermodynamic calculation databases GTOX and SGPS for predicting the melting behavior of the P-rich fuel ashes is discussed. The thermodynamic potential of altering the speciation of $\mathrm{P}$ towards the formation of more plant available phosphates using fuel mixtures in comparison with pure sewage sludge is studied. The predicted influence of the gas atmosphere and the process temperature on the type of phosphates and the melt formation in the ash fraction is investigated.

\section{Methodology}

\subsection{Fuel}

The input data for the thermodynamic calculations was based on the elemental ash composition of sewage sludge (SS), wheat straw (WS), and sunflower husks (SH), as shown in Table 1. For the analysis of these major ash-forming elements, an ICPAES according to EN 15290 was performed. The SS fuel was precipitated with both iron sulfate $\left(\mathrm{FeSO}_{4}, \mathrm{Fe}_{2}\left(\mathrm{SO}_{4}\right)_{3}\right)$ and poly aluminum chloride $\left(\mathrm{Al}_{\mathrm{n}}(\mathrm{OH})_{\mathrm{m}} \mathrm{Cl}_{3 \mathrm{n}-\mathrm{m}}\right)$ and obtained from a SYVAB plant in the south of Stockholm. WS, representing biomass fuels with high $\mathrm{K}$ and $\mathrm{Si}$ contents, was received from an animal food manufacturer in Thuringia, Germany. SH, representing biomass fuels rich in $\mathrm{K}$ and alkaline earth elements $(\mathrm{Ca}, \mathrm{Mg}$ ) with a lack of $\mathrm{Si}$ and $\mathrm{P}$, was obtained from a food supplier in Bulgaria. The resulting mixtures are sewage sludge + wheat straw (WSS) and sewage sludge + sunflower husks (SSH). For the thermodynamic calculations, these compositions were converted into molar ash-mixing ratios to allow for a better presentation in the graphs (see "Results").

\subsection{Thermodynamic modeling}

The thermodynamic equilibrium calculations were performed with the software FactSage 7.3 [20], based on global

Table 1 Main ash-forming elements in the fuels sewage sludge (SS), wheat straw (WS), and sunflower husks (SH) given in moles per kilogram of dry fuel (df)

\begin{tabular}{llll}
\hline Element & SS (mol/kg df) & WS (mol/kg df) & SH (mol/kg df) \\
\hline $\mathrm{Na}$ & 0.061 & 0.002 & 0.000 \\
$\mathrm{Mg}$ & 0.152 & 0.032 & 0.079 \\
$\mathrm{Al}$ & 0.482 & 0.005 & 0.001 \\
$\mathrm{Si}$ & 1.068 & 0.337 & 0.017 \\
$\mathrm{P}$ & 1.291 & 0.021 & 0.024 \\
$\mathrm{~K}$ & 0.066 & 0.216 & 0.191 \\
$\mathrm{Ca}$ & 0.873 & 0.071 & 0.095 \\
$\mathrm{Fe}$ & 1.182 & 0.002 & 0.001 \\
$\sum n$ & 5.175 & 0.686 & 0.408 \\
\hline
\end{tabular}


equilibrium calculations according to the minimization of Gibbs energy in the system. The databases GTOX (stoichiometric compounds, solutions, gas species) and SGPS (stoichiometric compounds, gas species) were used. The applicability of GTOX for the modeling of ash chemistry in P-rich systems has been shown previously $[21,22]$. The SGPS database was implemented to allow the formation of more $\mathrm{H}$ bearing stoichiometric compounds and gases, since GTOX only contains data for $\mathrm{H}, \mathrm{H}_{2} \mathrm{O}$, and $\mathrm{H}_{2}$. In the case of compound duplicates, the priority was given to GTOX, and the SGPS compound was suppressed. The calculations were focused on the description of an oxide melt formation, due to low stabilities of salt melts in the analyzed range of ash composition and temperature. Therefore, salt melt models were not included in the calculations. Additionally, the elements S and $\mathrm{Cl}$ were omitted since separate calculations including these elements showed low stability of sulfates and chlorides in the condensed phase.

The $\lambda$-value was chosen as set point for the gas conditions, representing the air-to-fuel ratio in a thermal conversion process. By definition, $\lambda=1$ in a stoichiometric mixture without excess $\mathrm{O}$. For the modeling of the combustion system, the gas atmosphere is set to guarantee fully oxidized conditions in the ash with $\lambda \approx 1.15\left(20\right.$ vol\% $\mathrm{CO}_{2}, 15$ vol $\% \mathrm{H}_{2} \mathrm{O}, 3-4$ vol $\% \mathrm{O}_{2}$, $\mathrm{N}_{2}$ ) to provide a flue gas composition similar to industrialscale applications. Gasification conditions were modeled with a thermodynamic equilibrium that guarantees the formation of $\mathrm{CO}(\lambda \approx 0.9)$, adjusting the counterpart $\mathrm{O}_{2}$ concentration according to the respective equilibrium equation in the model. This $\lambda$-value was chosen to identify the elements and compounds, which are most sensitive to partially reducing gas conditions. The ratios of $\mathrm{CO}_{2} / \mathrm{CO}$ and $\mathrm{H}_{2} \mathrm{O} / \mathrm{H}_{2}$ were determined by equilibrium in the gasification calculations. The molar ratio of input gas/ash elements was $\sim 100$ for all calculations. The elements and databases used with the considered solution models are given in Table 2.

The melt formation and $\mathrm{P}$ speciation were calculated and evaluated for the pure fuels and the fuel blends (WSS, SSH) in the temperature range from 600 to $1200{ }^{\circ} \mathrm{C}$. The fuel blends were modeled by ash-mixing ratios $(\alpha)$ from 100 mol.\% SS ash $(\alpha=0)$ to $100 \mathrm{~mol} . \% \mathrm{WS} / \mathrm{SH}$ ash $(\alpha=100)$ with $\Delta \alpha=0.5$, i.e., 201 different compositions per calculation. Due to the methodology, the calculated and therefore evaluated melt refers solely to the oxide melt in equilibrium. The calculations for the melt formation and the $\mathrm{P}$ speciation are carried out under both combustion and gasification atmospheres. The equilibrium precipitation calculations used melt formed under either combustion or gasification conditions, but the precipitation takes place under ambient temperature, pressure, and gas composition ( 79 vol $\% \mathrm{~N}_{2}, 21$ vol\% $\mathrm{O}_{2}$ ). Within the precipitation calculation model, all elements in the melt and in compounds precipitated from the melt are cooled down to $20^{\circ} \mathrm{C}$.
Table 2 Elements, compounds, and solution models used for the thermodynamic equilibrium calculations in FactSage. Database compounds are given in italics

\section{Elements}

$\mathrm{H}, \mathrm{C}, \mathrm{N}, \mathrm{O}, \mathrm{Na}, \mathrm{Mg}, \mathrm{Al}, \mathrm{Si}, \mathrm{P}, \mathrm{K}, \mathrm{Ca}, \mathrm{Fe}$

Database - GTOX (solution models)

MeO: $\mathrm{CaO}, \mathrm{MgO}, \mathrm{K}_{2} \mathrm{O}, \mathrm{Al}_{2} \mathrm{O}_{3}, \mathrm{FeO}$ OLIV: $(\mathrm{Ca}, \mathrm{Fe}, \mathrm{Mg})(\mathrm{Ca}, \mathrm{Fe}, \mathrm{Mg}) \mathrm{SiO}_{4}$ Garn: $(\mathrm{Al}, \mathrm{Fe})_{2} \mathrm{Ca}_{3} \mathrm{Si}_{3} \mathrm{O}_{12}$

MULL: $\mathrm{Al}_{2}(\mathrm{Al}, \mathrm{Fe}, \mathrm{Si}) \mathrm{O}_{5}$

CAO: $\mathrm{Ca}(\mathrm{Al}, \mathrm{Fe})_{2} \mathrm{O}_{4}$

LEUC: $K(\mathrm{Al}, \mathrm{Fe}) \mathrm{Si}_{2} \mathrm{O}_{6}$

FSPA: $\mathrm{K}(\mathrm{Al}, \mathrm{Fe}) \mathrm{Si}_{3} \mathrm{O}_{8}$

MELM: $\mathrm{Ca}_{2} \mathrm{Si}(\mathrm{Al}, \mathrm{Mg})(\mathrm{Al}, \mathrm{Si}) \mathrm{O}_{7}$

NAFH: $K(\mathrm{Al}, \mathrm{Fe}) \mathrm{O}_{2}$

Stoichiometric solid compounds

LIOS-oxide melt containing:

$\mathrm{O}, \mathrm{Na}, \mathrm{Mg}, \mathrm{Al}, \mathrm{Si}, \mathrm{P}, \mathrm{K}, \mathrm{Ca}, \mathrm{Fe}$

C3PL: $(\mathrm{Ca}, \mathrm{Mg})_{3}\left(\mathrm{PO}_{4}\right)_{2}$

CMP: $(\mathrm{Ca}, \mathrm{Mg}) \mathrm{CaP}_{2} \mathrm{O}_{7}$

C2F: $\mathrm{Ca}_{2}(\mathrm{Al}, \mathrm{Fe})_{2} \mathrm{O}_{5}$

ALPM: $(\mathrm{Al}, \mathrm{Si})(\mathrm{P}, \mathrm{Si}) \mathrm{O}_{4}$

SIOM: $(\mathrm{Al}, \mathrm{Si})(\mathrm{P}, \mathrm{Si}) \mathrm{O}_{4}$

K3PM: $K_{4}(\mathrm{Ca}, \mathrm{Mg}) \mathrm{P}_{2} \mathrm{O}_{8}$ CORU: (Al, $\mathrm{Fe})_{2} \mathrm{O}_{3}$

Database - SGPS (stoichiometric compounds)

Gas compounds

Stoichiometric solid compounds

\section{Results}

\subsection{Ash chemistry potential}

The chemical potential for possible ash transformation reactions in the fuel blends determines the thermodynamic driving forces as calculated by FactSage. Therefore, the change in elemental composition as a function of the fuel-mixing ratio is shown for both investigated fuel mixtures in Fig. 1. The illustrated dataset displays the dominance of the elements derived from SS for a wide range of the fuel-mixing ratios. Fuel blends containing more than $50 \mathrm{wt} \%$ of SS do not differ significantly from pure SS in their chemical reaction potential. This observation is substantiated by the fact that the ash of a $50 / 50 \mathrm{wt} \%$ fuel blend for both SSH and WSS respectively contains about 90 mol.\% elements derived by the sewage sludge fuel.

The most important trend in both analyzed fuel blends is the depletion of $\mathrm{P}, \mathrm{Fe}$, and $\mathrm{Al}$ in combination with an increase of $\mathrm{K}$ towards higher shares of agricultural residue in the fuel blend. The main difference between SSH mixtures and WSS mixtures is the share of $\mathrm{Si}$ in the ash, which is increasing in WSS mixtures and decreasing in SSH mixtures. These shifts in the elemental composition must be considered for a concise interpretation of the melting behavior and the $\mathrm{P}$ speciation, since most of the elemental ratios (e.g., $\mathrm{P} / \mathrm{K}$ and $\mathrm{P} / \mathrm{Si}$ ) are changed significantly. Note that this change in elemental shares and ratios is accompanied by a significant decrease in total molar amount of ash elements per kilogram of dry fuel towards higher shares of agricultural residues in the mixtures.

This dominance of the SS ash elements in illustrations displaying elemental composition of fuel blends as a function of fuel-mixing ratios (w) can be bypassed by using molar ash- 


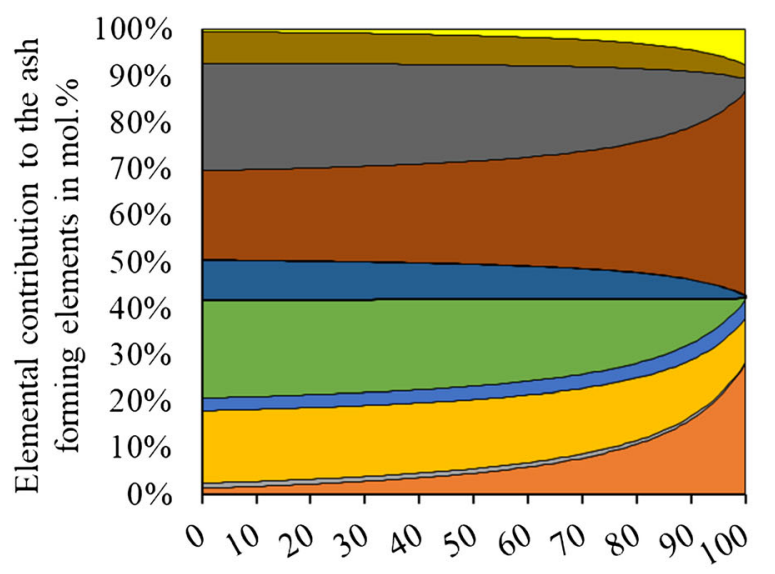

Share of wheat straw in the fuel blend in wt. $\% \mathrm{df}$
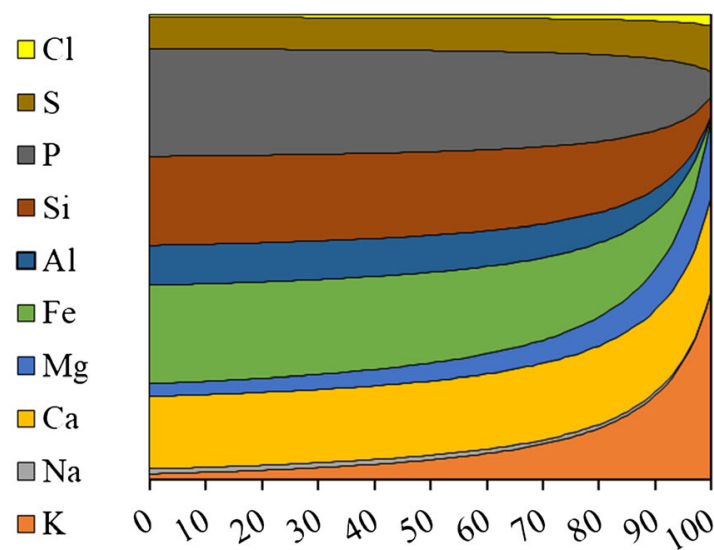

$100 \%$

$90 \%$

$80 \%$

$70 \%$

$60 \%$

$50 \%$

$40 \%$

$30 \%$

$20 \%$

$10 \%$

$0 \%$

$\begin{array}{llllllllllll}0 & 10 & 20 & 30 & 40 & 50 & 60 & 70 & 80 & 90 & 0 & 0\end{array}$

Share of sunflower husks in the fuel blend in wt.\% df

Fig. 1 Elemental composition in the main ash-forming elements (excluding $\mathrm{O}$ ) as a function of the fuel-mixing ratio for the fuel blends WSS (left) and SSH (right)

mixing ratios $(\alpha)$ as function argument instead. By this method, the area where the chemical composition changes significantly is magnified and allows for better visibility of the important transitions in the thermodynamic potential due to changing mixtures. The equation to obtain the share of agricultural residue in the fuel blend as a function of the ashmixing ratio by inserting the element sum values (see Table 1) is:

$$
\begin{aligned}
w_{W S \mid S H}(\alpha)= & \sum n_{S S} \times \alpha \\
& \times\left(\sum n_{S S} \times \alpha-\sum n_{W S \mid S H} \times \alpha+\sum n_{W S \mid S H}\right)^{-1}
\end{aligned}
$$

\subsection{Initial melt formation}

To investigate which ash composition may trigger melt formation, the initial melt formation (IMT) as a function of the molar mixing ratio of SS ash with each individual agricultural fuel ash $(\alpha)$ was calculated and is presented in Fig. 2. Pure SS ash displays a comparably low IMT of $780^{\circ} \mathrm{C}$ under combustion condition and $710^{\circ} \mathrm{C}$ under gasification conditions. The initially formed melt contains mainly $\mathrm{P}, \mathrm{Si}$, and $\mathrm{Fe}$ in both cases. Sensitivity analysis revealed that the main cause for the IMT below $800{ }^{\circ} \mathrm{C}$ was the surplus of $\mathrm{P}$ and $\mathrm{Fe}$ in these ashes, making the formation of Fe phosphates thermodynamically favorable. The decrease of IMT under gasification conditions correlates with the presence of non-fully oxidized iron phosphates, containing $\mathrm{Fe}^{2+}$ instead of $\mathrm{Fe}^{3+}$. The share of $\mathrm{Fe}^{2+}$ in the Fe species in all ash mixtures under gasification conditions was higher than 90 mol.\%; however, the decrease of IMT was only obtained when $\mathrm{Fe}^{2+}$-containing phosphates were formed. As the share of SS in the dry fuel blend decreases to $50 \mathrm{wt} \%$, the IMT increases rapidly in both mixtures and regardless of the gas conditions. This IMT increase is accompanied by a significantly lower Fe share in the initially formed melt. This decrease in Fe content ranged from 24 to 6 mol.\% under combustion conditions and from 35 to 22 mol.\% under gasification conditions, on an $\mathrm{O}$-free basis. Furthermore, the $\mathrm{P}$ share in this initially formed melt decreases by $10 \mathrm{~mol} \%$. Under combustion conditions, the melt shares of
Fig. 2 Initial melting temperature (IMT) of sewage sludge (SS) ash mixtures with wheat straw (WS) or sunflower husks $(\mathrm{SH})$ under combustion and gasification conditions as a function of the share of agricultural fuel ash elements on an $\mathrm{O}$-free basis $(\alpha)$. The dotted lines show the fuel-mixing ratio necessary to obtain the corresponding ash-mixing ratio

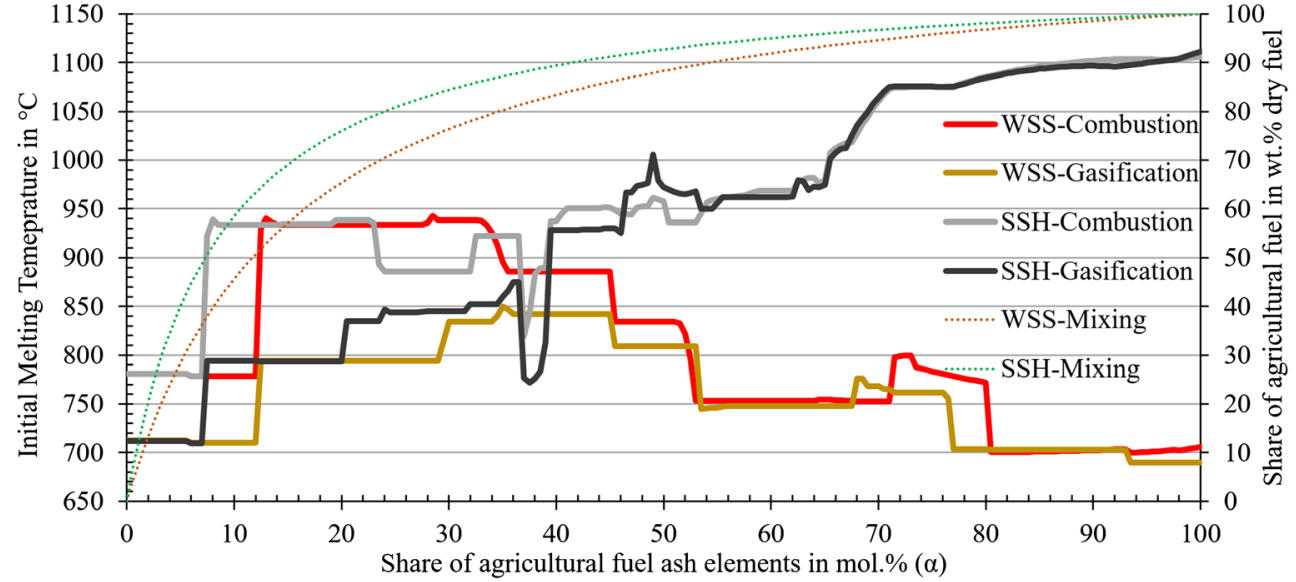


$\mathrm{Si}, \mathrm{K}, \mathrm{Al}$, and $\mathrm{Mg}$ increase after the IMT increment, whereas under gasification conditions, the melt shares of $\mathrm{Al}, \mathrm{K}, \mathrm{Ca}$, and $\mathrm{Mg}$ increase (both itemizations are in order of the increment magnitude).

For WSS mixtures, the IMT stays somewhat constant in the $\alpha$-range from 0.1 to 0.3 , although it is on a lower level under gasification conditions. The IMT drop for WSS ash under combustion conditions occurs due to the transition from a mixed PSi-dominated initial melt to a melt predominantly composed of $\mathrm{K}$ silicates, which have low melting points. On the other hand, the IMT under gasification conditions increases around $\alpha=0.3$, due to lower amounts of $\mathrm{Fe}$ and $\mathrm{P}$ being available for the melt formation, where $\mathrm{Fe}^{2+}$ is particularly important for the initial melt. The subsequent decrease of IMT under both analyzed conditions occurs due to more $\mathrm{K}$ silicates being formed by the surplus of $\mathrm{K}$ and $\mathrm{Si}$ in the increasing share of wheat straw ash. Beyond $\alpha=$ 0.5 , the trends for combustion and gasification converge mostly and display an incline, except for a slight increased IMT around $\alpha=0.75$, which was due to enhanced incorporation of $\mathrm{Ca}$ in the melt. Mixtures above $\alpha>0.8$ formed initial melts highly dominated by $\mathrm{K}$ silicates ( $>80 \mathrm{~mol} . \%$ ) and created at temperatures around $700{ }^{\circ} \mathrm{C}$.

SSH mixtures display a constant IMT in the $\alpha$-range from 0.1 to 0.2 . Under combustion conditions, this is followed by fluctuating IMT results. The melt composition shows that the drops in IMT are attributed to the formation of more K-Si-rich initial melts. As the fuel mixture ash is more depleted of both $\mathrm{Fe}$ and $\mathrm{Si}$ while enriched in $\mathrm{K}, \mathrm{Ca}$, and $\mathrm{Mg}$ towards higher $\alpha$-values, the potential to incorporate especially $\mathrm{Si}$ in the initial melt decreases since $\mathrm{Si}$ forms primarily stable compounds such as $\mathrm{K}_{2} \mathrm{CaSiO}_{4}$ in the calculations. Beyond $\alpha=0.5$, the initial melt formed by $\mathrm{SSH}$ mixtures mainly contains $\mathrm{K}, \mathrm{Ca}, \mathrm{Mg}$, and $\mathrm{P}$. All these elements increase their melt share continuously up to pure SH fuel ash, whereas $\mathrm{Si}$ and Fe display an incline in the initial melt composition. Sensitivity analysis in the area where the trends for combustion and gasification converge shows that the convergence in IMT coincides with a convergence of the $\mathrm{Fe}$ and $\mathrm{Ca}$ contents in the respective initial melt.

\subsection{Melt development}

The melting behavior of specific ash-mixing ratios was further analyzed at higher temperatures to investigate the dependency of the melt quantity on the ash composition and the gas atmosphere. This analysis showed a significant dependency on the fuel blends and the influence of the gas atmosphere. The temperatures at which a certain fraction of the ash is present as a melt are shown in Table 3 for the pure fuels and eight specific mixtures with WS or SH. The molar shares of the melt are given in terms of all condensed ash compounds excluding oxygen to set the focus on the chemical potential of the melt. Furthermore, the temperature at which no more melt is formed but elements are rather volatilized from the melt is shown.
Comparing the pure fuels, WS had the lowest IMT, followed by SS and SH. An important characteristic of WS ash was that a large fraction of the ash melted in a small temperature interval. In the calculations, this led to the incorporation of more than $75 \mathrm{~mol} . \%$ of the WS ash elements in the melt within the temperature interval $700-740{ }^{\circ} \mathrm{C}$ for combustion conditions and $690-740{ }^{\circ} \mathrm{C}$ for gasification conditions.

In case of the SS ash, the temperature gap until major parts of the ash melted was significantly larger, though more dependent on the gas conditions. Under combustion conditions, the temperature interval for incorporation of $25 \mathrm{~mol} . \%$ of the ash elements was almost $240^{\circ} \mathrm{C}$ and complete melting of the ash did not occur up to $1200{ }^{\circ} \mathrm{C}$. Under gasification conditions, the previously mentioned temperature interval was just about $100{ }^{\circ} \mathrm{C}$ and was followed by more melt formation per temperature increment than in the combustion calculations.

Melt formation results for pure $\mathrm{SH}$ ash displayed no melt formation below $1100{ }^{\circ} \mathrm{C}$ and little influence of the gas conditions. In the analyzed temperatures up to $1200^{\circ} \mathrm{C}$, up to 33 mol.\% of the ash elements could be incorporated in the melt. Due to the surplus of cation formers $\mathrm{K}, \mathrm{Ca}$, and $\mathrm{Mg}$, forming mainly carbonates and oxides, in combination with the lack of the anion formers Si and $\mathrm{P}$, higher shares of melt could not be obtained. The calculations show that $\mathrm{CaO}$ and $\mathrm{MgO}$ are stable solids and have no tendency to be incorporated in the melt, if they do not have sufficient reaction potential with $\mathrm{Si}$ or P.

The results for the melting behavior of the mixtures, as listed in Table 3, indicate no linear trends dependent of the mixing ratios. Shares of $20 \mathrm{~mol} . \%$ ash of either WS or SH in the mixtures with SS gave similar results, as the IMT was elevated from the low IMT of pure SS (see Fig. 2), but the subsequent incorporation of ash elements is in a smaller temperature interval. The elevation of the IMT is associated with the depletion of $\mathrm{Fe}$ and also $\mathrm{P}$, as previously described in detail. Notably, all the mixtures display this phenomenon of incorporating high percentages of the ash elements in the melt in a small temperature interval upon initial melt formation. The reason for this behavior is the more mixed elemental pool, which provides not only the diverse spectrum in the $\mathrm{SS}$ ash $(\mathrm{P}, \mathrm{Si}, \mathrm{Ca}, \mathrm{Fe}, \mathrm{Al})$ but additionally $\mathrm{K}$. The absolute temperature at which these melt quantity increments occur correlates with the potential of $\mathrm{K}$ silicate formation, which is higher for WSS mixtures due to the additional Si in WS ash.

The results for the volatilization of elements from the melt fraction display a significant dependence on the elemental composition of the ash. Pure SS ash and most WSS mixtures did not display volatilization of ash elements from the melt in the analyzed temperature range. The mixture with $80 \mathrm{~mol} . \%$ WS ash and pure WS ash showed potential to release minor amounts of $\mathrm{K}$ from the melt. The trend is different for SSH mixtures, as most of the analyzed mixtures formed substantial amounts of volatilized $\mathrm{K}$ compounds at higher temperatures. Additional to the release of $\mathrm{K}$ from the molten phase (see Table 3), a significant decomposition of solid $\mathrm{K}$ and $\mathrm{Na}$ 
Table 3 Initial melting temperature (IMT), the temperatures at which the share of melt in the condensed phases is $25 / 50 / 75 \mathrm{~mol} . \%$, and initial temperature when elements are volatilized from the melt for the pure fuels and specific ash-mixing ratios $(\alpha)$. Temperatures are given under

\begin{tabular}{|c|c|c|c|c|c|}
\hline Fuel & $\operatorname{IMT}\left({ }^{\circ} \mathrm{C}\right)$ & $\begin{array}{l}\text { Melt share } \\
25 \text { mol. } \%\left({ }^{\circ} \mathrm{C}\right)\end{array}$ & $\begin{array}{l}\text { Melt share } \\
50 \mathrm{~mol} . \%\left({ }^{\circ} \mathrm{C}\right)\end{array}$ & $\begin{array}{l}\text { Melt share } \\
75 \text { mol. } \%\left({ }^{\circ} \mathrm{C}\right)\end{array}$ & $\begin{array}{l}\text { Initial melt } \\
\text { volatilization }\left({ }^{\circ} \mathrm{C}\right)\end{array}$ \\
\hline Pure WS & $706(690)$ & $708(700)$ & $722(720)$ & $738(738)$ & $890(884)$ \\
\hline $\begin{array}{c}20 \% \mathrm{SS} \\
80 \% \mathrm{WS}\end{array}$ & $774(704)$ & $780(736)$ & $824(790)$ & $864(838)$ & $1150(1068)$ \\
\hline $\begin{array}{l}40 \% \mathrm{SS} \\
60 \% \mathrm{WS}\end{array}$ & $754(750)$ & 754 (776) & $818(816)$ & $984(870)$ & $>1200(>1200)$ \\
\hline $\begin{array}{c}60 \% \mathrm{SS} \\
40 \% \mathrm{WS}\end{array}$ & $886(844)$ & $886(844)$ & $906(844)$ & $1052(882)$ & $>1200(>1200)$ \\
\hline $\begin{array}{c}80 \% \mathrm{SS} \\
20 \% \mathrm{WS}\end{array}$ & $936(796)$ & $936(796)$ & 998 (824) & $1140(882)$ & $>1200(>1200)$ \\
\hline Pure SS & $782(714)$ & $1018(812)$ & $1090(840)$ & $1112(924)$ & $1200(<1200)$ \\
\hline $\begin{array}{l}80 \% \mathrm{SS} \\
20 \% \mathrm{SH}\end{array}$ & $940(794)$ & $942(838)$ & $976(852)$ & $1080(872)$ & $>1200(>1200)$ \\
\hline $\begin{array}{l}60 \% \mathrm{SS} \\
40 \% \mathrm{SH}\end{array}$ & 938 (916) & $950(916)$ & $972(950)$ & $976(1002)$ & $1016(1130)$ \\
\hline $\begin{array}{l}40 \% \mathrm{SS} \\
60 \% \mathrm{SH}\end{array}$ & $970(960)$ & $970(976)$ & $998(1012)$ & $1036(1048)$ & $1076(1112)$ \\
\hline $\begin{array}{l}20 \% \mathrm{SS} \\
80 \% \mathrm{SH}\end{array}$ & $1086(1084)$ & 1098 (1098) & 1106 (1106) & $-(-)^{*}$ & 1166 (1126) \\
\hline Pure SH & $1106(1114)$ & $1150(1152)$ & $-(-) *$ & $-(-)^{*}$ & $1156(1160)$ \\
\hline
\end{tabular}

compounds, mainly $\mathrm{K}_{2} \mathrm{CO}_{3}$ and $\mathrm{Na}_{2} \mathrm{CO}_{3}$, is obtained in SHrich mixtures. The volatilized $\mathrm{K}$ and $\mathrm{Na}$ are mainly found as hydroxides $(\mathrm{KOH}, \mathrm{NaOH})$ in the gas phase.

\subsection{Phosphorus speciation}

The fate of $\mathrm{P}$ at specific process temperatures was analyzed in terms of the $\mathrm{P}$ association with different groups of elements $(\mathrm{Ca} / \mathrm{Mg}, \mathrm{K}(+\mathrm{Ca} / \mathrm{Mg}), \mathrm{Fe} / \mathrm{Al}$, melt). These groups may facilitate the determination of plant available $\mathrm{P}$ fractions in future analyses. The grouping is focused on the accentuation of $\mathrm{K}$ bearing phosphates, which means that the groups $(\mathrm{Ca}, \mathrm{Mg})$ phosphates and ( $\mathrm{Al}, \mathrm{Fe}$ )-phosphates may incorporate additional elements such as $\mathrm{Si}$ (e.g., through solid solution models), but no $\mathrm{K}$. All the K-bearing phosphates in the calculation, e.g., $\mathrm{KMgPO}_{4}, \mathrm{CaK}_{2} \mathrm{P}_{2} \mathrm{O}_{7}$, and $\mathrm{CaKPO}_{4}$, are subsumed under the term K-phosphates. It is important to be aware of the lacking thermodynamic data for several phosphates incorporating 3 different cations, such as merrillite $\left(\mathrm{Ca}_{9} \mathrm{NaMg}\left(\mathrm{PO}_{4}\right)_{7}\right)$.

The $\mathrm{P}$ speciation was analyzed for all ash-mixing ratios in a temperature range of 700 to $1200{ }^{\circ} \mathrm{C}$. Depictions of the $\mathrm{P}$ association between 700 and $1100{ }^{\circ} \mathrm{C}$ for the mixtures with WS and SH respectively under combustion and gasification conditions are shown in Fig. 3. The lower temperature boundary for the depiction was chosen to show the chemical potential for the formation of solid $\mathrm{P}$ compounds at $700{ }^{\circ} \mathrm{C}$. The results for $1200{ }^{\circ} \mathrm{C}$ are not shown because all the $\mathrm{P}$ was incorporated in the melt fraction, regardless of the mixture and the combustion conditions and (in parenthesis) under gasification conditions. The analyzed $\mathrm{T}$ increment was $\Delta T=2{ }^{\circ} \mathrm{C}$. * Corresponding melt quantity cannot be formed for the given ash composition in the calculations 

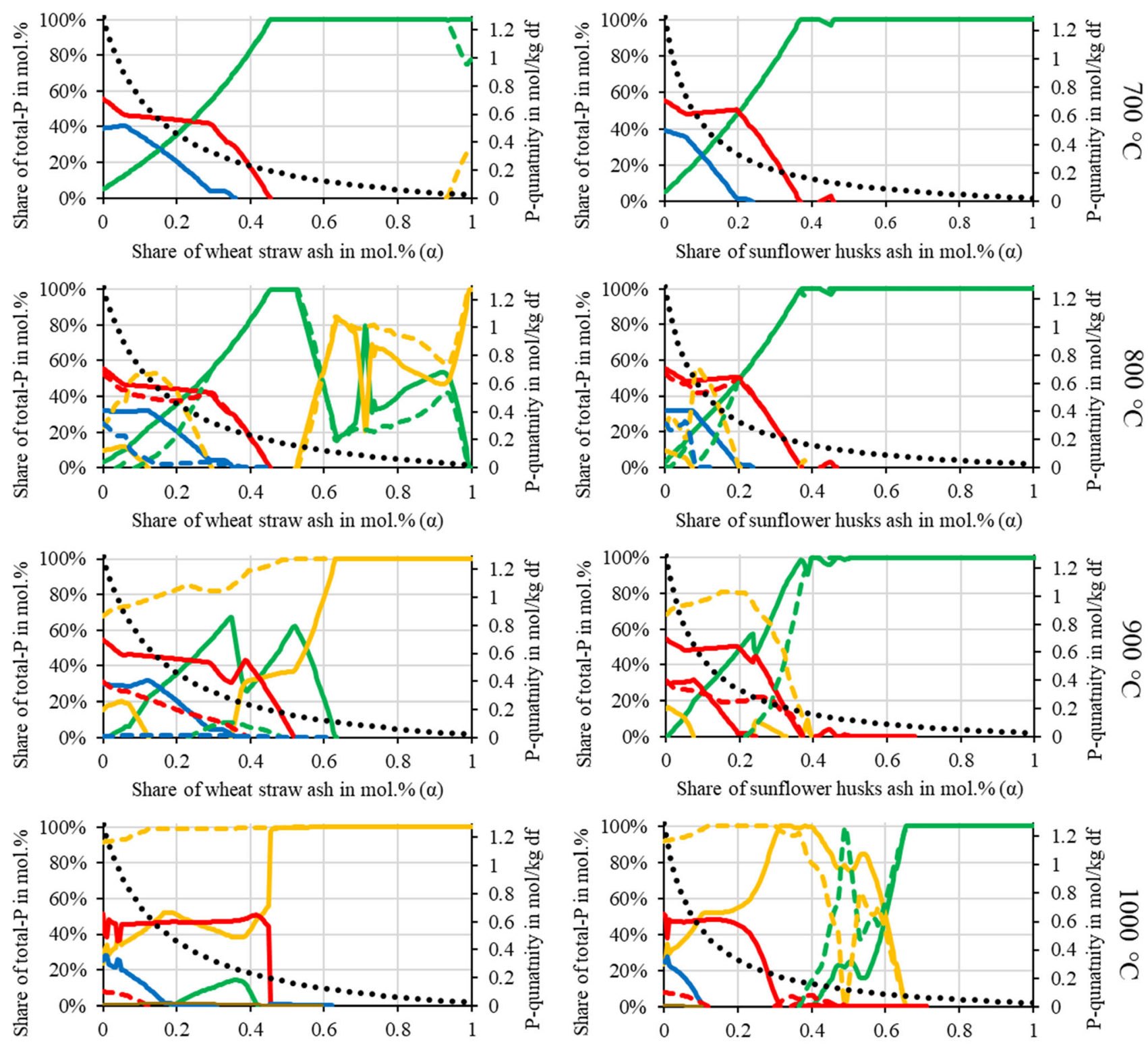

Share of wheat straw ash in $\mathrm{mol} \%(\alpha)$
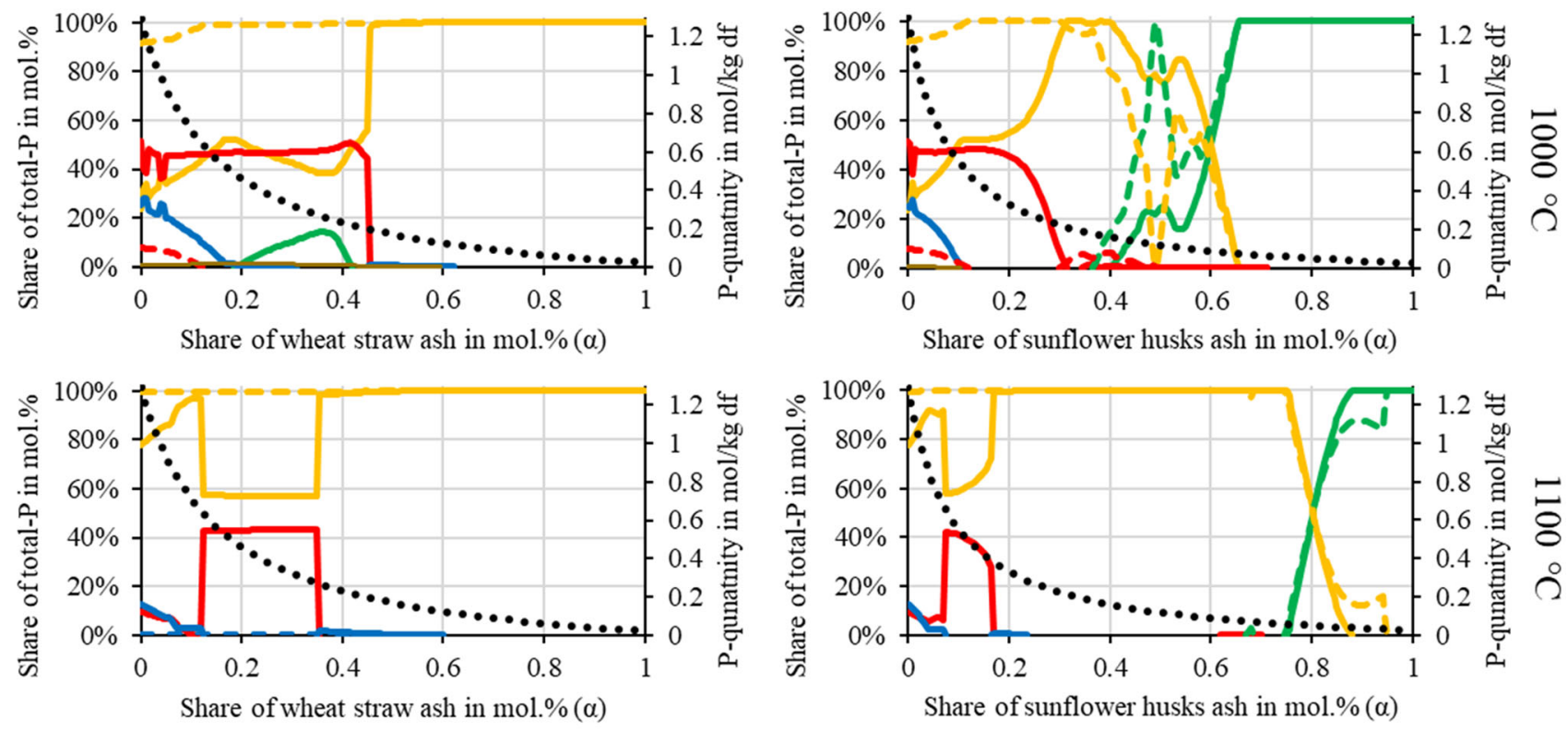

$\longrightarrow \mathrm{P}$ in $\mathrm{K}$-phosphates $\longrightarrow \mathrm{P}$ in melt $\longrightarrow \mathrm{P}$ in $(\mathrm{Ca}, \mathrm{Mg})$-phosphates

— $\mathrm{P}$ in $(\mathrm{Al}, \mathrm{Fe})$-phosphates $\quad \cdots . P$ P per kg fuel

Fig. $3 \mathrm{P}$ speciation for SS mixtures with WS (left) and SH (right) at different temperatures and under combustion conditions (continuous line) and under gasification conditions (dashed line) in mol.\% of total P. The

${ }^{\circ} \mathrm{C}$ and affected to a lesser degree up to $1000^{\circ} \mathrm{C}$. The $(\mathrm{Ca}-\mathrm{Mg})$ phosphates remained partially in solid state even at higher total molar amount of $\mathrm{P}$ in the respective fuel blend is indicated by the black dotted line in $\mathrm{mol} \mathrm{P} / \mathrm{kg}$ df

temperatures, when all the other $\mathrm{P}$ species are already incorporated in the melt. 
The results for SSH mixtures are almost identical to the results in WSS mixtures when only small amounts of SH are contained in the fuel mixture. The main difference to the WSS mixtures is that $\mathrm{K}-(\mathrm{Ca}, \mathrm{Mg})$ phosphates are more stable towards higher amounts of SH ash elements in the mixture; i.e., $\mathrm{P}$ is incorporated to a lesser degree in the melt fraction.

\subsection{Melt precipitation}

As shown previously, a significant amount of $\mathrm{P}$ can be contained in the molten ash fraction depending on the conditions and the fuel blends. Since the ashes will undergo a cooling process before any further processing may be performed, it is of interest which compounds precipitate from the melt under equilibrium cooling. For this purpose, crystallization calculations for the melt fraction, i.e., excluding the solid fraction, were performed and the results are illustrated in Fig. 4. The colored bars show the molar amount of different $P$ species precipitated from the starting temperature when 50 mol.\% of the fuel ash elements are incorporated in the molten fraction (see Table 3). The error bars refer to the amount of $\mathrm{P}$ species precipitated from the respective temperature incorporating $25 \mathrm{~mol} . \%$ and $75 \mathrm{~mol} . \%$ of the ash elements in the melt (on an O-free basis). The precipitation calculations were performed under oxidizing conditions.

The outcome of the equilibrium precipitation analysis shows that $\mathrm{P}$ in the melt precipitates almost solely as K-containing phosphates if sufficient $\mathrm{K}$ is available in the melt. Melt formed by pure SS ash does not comply with this criterion; therefore, mostly $(\mathrm{Ca}, \mathrm{Mg})$ phosphates and $(\mathrm{Fe}, \mathrm{Al})$ phosphates precipitate from the melt. The interval of possible precipitation of $\mathrm{K}$ phosphates is very narrow around the value for $50 \%$ SS ash melt (green bar), which states that K (as a limiting factor in pure SS ashes) is incorporated almost completely in the melt above the
IMT. The influence of the gas atmosphere is mainly on the distribution between the other phosphate precipitates. As melt formed by SS ash under gasification conditions is enriched in $\mathrm{Fe}$, the precipitates are enriched in Fe phosphates (blue bar).

For both presented fuel blends, the melt is K-enriched, and phosphates are mainly precipitated as K-bearing phosphates. Comparison of the phosphates from precipitation and the total chemical potential in the ash composition shows that the formation of K-bearing phosphates is favored by the formation of melt. This effect occurs mainly when the melt share is 50 mol.\% or lower, because $\mathrm{K}$ and $\mathrm{P}$ are represented disproportionally high in these melts, whereas $\mathrm{Ca}$ is underrepresented at this stage of melt quantity formation. The results also show that $\mathrm{K}$ phosphates are preferred over $\mathrm{K}$ silicates when $\mathrm{K}$ is the limiting factor in the melt composition. With higher shares of agricultural residue in the mixture, $\mathrm{P}$ becomes the limiting element for $\mathrm{K}$ phosphate precipitation in the formed melts. The main non-phosphate compounds found by melt precipitation were Fe oxide and quartz in SS-rich ashes, $\mathrm{K}-(\mathrm{Mg}, \mathrm{Ca})$ silicates and quartz in WS-rich ashes, and $(\mathrm{K}, \mathrm{Mg}, \mathrm{Ca})$ carbonates in $\mathrm{SH}-$ rich ashes.

\section{Discussion}

\subsection{Melt formation}

Interpretation of the results for the initial melting temperature (IMT) shown in Fig. 1 is focused on the influence of the gas atmosphere and the different fuel compositions. The decrease in IMT for all ash mixtures dominated by SS occurs due to the surplus of $\mathrm{Fe}$ and $\mathrm{P}$ in these ashes, forming Fe phosphates that take part in the initial melt formation. In previous studies, the low IMT in SS combustion was attributed to the formation of alkali
Fig. 4 P speciation in the precipitated phases from the melts of different mixtures of SS with WS and SH respectively. The charts illustrate the data points for precipitation from the temperature where $50 \mathrm{~mol} . \%$ of the ash are present in the molten phase. The intervals represent the results for the temperatures of $25 \mathrm{~mol} . \%$ (lower limit) and $75 \mathrm{~mol} \%$ (upper limit) incorporation in the melt

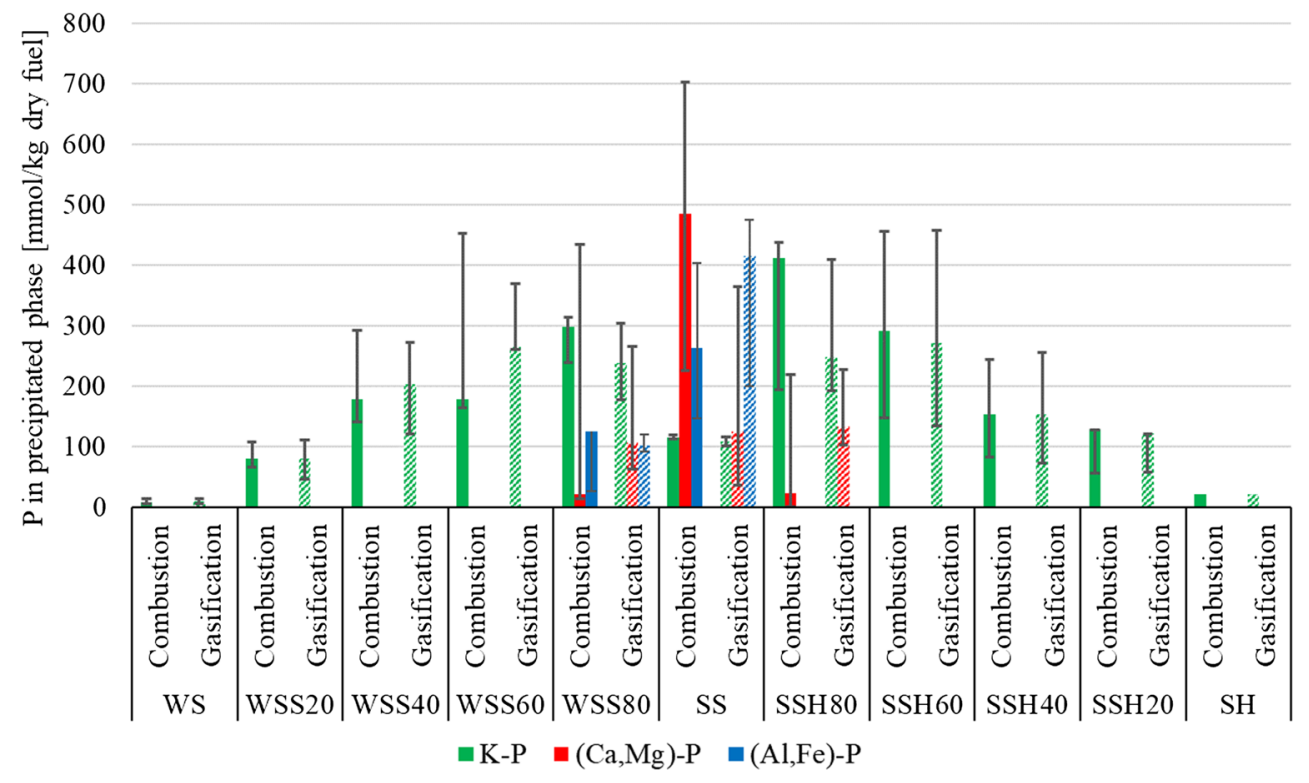


phosphates and $\mathrm{Fe}_{2} \mathrm{O}_{3}-\mathrm{SiO}_{2}$ eutectics [23]. The abrupt rise in IMT when approximately $10 \mathrm{~mol} . \%$ agricultural residue ash is present may be attributed to the disappearance of the $\mathrm{P}$ surplus. The elemental composition at this point allows for the formation of more stable phosphates, e.g., $\mathrm{K}_{2} \mathrm{CaP}_{2} \mathrm{O}_{7}$, and $\mathrm{Fe}$ oxides, which inhibits the incorporation of $\mathrm{Fe}$ and $\mathrm{P}$ into the melt. The decrease of $\mathrm{Fe}$ accompanied by the increase of $\mathrm{K}$ as the share of SS ash decreases seems to favor the formation of more stable $\mathrm{K}$ phosphates (e.g., $\mathrm{KMgPO}_{4}$ ). Based on the different compound formations between combustion and gasification conditions, the oxidation state of the $\mathrm{Fe}$ oxides $\left(\mathrm{Fe}^{2+}, \mathrm{Fe}^{3+}\right)$ and formation of vivianite $\left(\mathrm{Fe}_{3}\left(\mathrm{PO}_{4}\right)_{2}\right)$ may be the dominating factor for the decreased IMT under gasification conditions. This case is important to consider since a large fraction of $\mathrm{P}$ in precipitated SS may be bound to $\mathrm{Fe}^{2+}$ as vivianite [24], an important resource for P recovery [25].

The difference in IMT towards the pure SH and WS can be explained by the formation of low-melting K silicates in the WS ash, which has been documented in previous studies $[14,26]$. In the equilibrium calculations, the Si-lean $\mathrm{SH}$ ash tends to form ash enriched in $\mathrm{CaO}$ and $\mathrm{MgO}$, which are highly stable up to higher temperatures. Furthermore, the results showed qualitative volatilization of $\mathrm{K}$ in the SH-rich ashes, which can be mainly attributed to the lack of Si and P in the SH ash. Both SS- and WS-rich ashes provide a high level of anionic compounds, as referred to by Skoglund [27], e.g., $\mathrm{PO}_{4}{ }^{3-}, \mathrm{SiO}_{4}{ }^{4-}$, which may react with $\mathrm{K}$ and create solid compounds. SH-rich ashes lack these anion formers, leading to an elevated formation of $\mathrm{K}$ carbonate, which may be volatilized at higher temperatures. The presence of carbonates under gasification conditions indicates that the calculations solely based on the formation of an oxide melt are insufficient at high share $\mathrm{SH}$ ash and the formation of a salt melt should be considered. Previous research stated higher stability of $\mathrm{K}_{2} \mathrm{CO}_{3}$ in a Si-lean and $\mathrm{CO}_{2}$-rich environment [28]. Detailed studies for the gaseous release of $\mathrm{K}$ would need to focus on the reaction with $\mathrm{Cl}$ in the calculations, as the formation of $\mathrm{KCl}$ is common in thermal conversion processes of biomass [29, 30].

The analysis of the melting behavior provided in Table 3 indicates several effects of the fuel-mixing and the gas atmosphere, which may influence the thermochemical conversion process. The mixtures with sunflower husks and wheat straw melt up to $50 \mathrm{~mol} . \%$ in a small temperature interval. The composition data suggests that this result is caused by excessive inclusion of $\mathrm{K}$ and $\mathrm{P}$ in the melt, which is enhanced by further addition of K-rich agricultural fuel. Previous research found that excess of $\mathrm{P}$ and $\mathrm{K}$ promoted the formation of lowmelting phosphates [14]. Although the initial melt formation was shifted towards higher temperatures, the melt starts to dissolve and incorporate a large fraction of silicates and phosphates soon thereafter. Total melting of SH-rich ash mixtures and pure $\mathrm{SH}$ ash was inhibited by the formation of stable alkaline oxides $(\mathrm{CaO}, \mathrm{MgO})$ and volatilization of $\mathrm{K}$.

In reality, the practical melting behavior of these fuel blends might be significantly different from these theoretical equilibrium calculations due to various reasons. The assumption that in a fuel blend, every individual ash element is readily available to react or be associated in the melt is not reflecting the real capability of mixing technology. Even under perfect mixing parameters, the original fuel will maintain its structure partially within the mixture pellets, which means that elements present in different pure fuels might not interact as freely as the calculations suggest. This interaction barrier should also be considered when highly stable solid compounds are incorporated in the melt, solely because of the minimization of Gibbs free energy in thermodynamic equilibrium. Another aspect is that the interaction between solid compounds is considered to have no kinetic limitations in equilibrium calculations. The reactivity of the ash elements, in reality, will be defined by their state of matter. It needs to be considered that an individual pure fuel fraction in the ash could melt or volatilize to enhance the interaction with the ash material from the other fuels. Furthermore, a complete investigation of the melting behavior must include additional information in the thermodynamic model regarding salt-incorporating melt systems, melt viscosity models, and continuous process modeling. Inclusion of these parameters in the analysis requires an enhancement of the databases and the process boundary definitions in the equilibrium calculations.

\subsection{Phosphorus speciation and precipitation}

The results of the thermodynamic calculations at specific temperatures over the entire range of mixture ratios show the potential of using SS mixtures with agricultural residues for the creation of Kbearing phosphates. The desired shift from $\mathrm{Ca} / \mathrm{Mg}$ phosphates and $\mathrm{Fe} / \mathrm{Al} / \mathrm{Si}$ phosphates towards $\mathrm{K}$ phosphates when using fuel blends was identified. It could be shown that K-bearing phosphates are thermodynamically favored in a P-limited ash environment. Therefore, the calculations indicate that the entire $\mathrm{P}$ was present in K-bearing phosphates (or as molten P compounds) when the agricultural residue ash was the dominating ash fraction. The results obtained for the $\mathrm{P}$ association in this work are in accordance with previous findings of the possibility to change the $\mathrm{P}$ speciation in sewage sludge ashes by adding alkali-rich additives [12]. Modeling a function of the $\mathrm{P}$ species in dependence of a fuel blend, process temperature, and gas atmosphere has shown its applicability in this theoretic approach. This could serve as a basis for experiments, aiming to validate the modeled results, thereby obtaining an approximation of how much empirical data deviates from thermodynamic equilibrium data. Knowledge about the deviating factors between theory and experiment could establish a baseline to repeat such a methodology for other types of fuel blends to investigate their potential of $\mathrm{P}$ recovery.

The thermodynamic modeling of the $\mathrm{P}$ speciation must be evaluated critically too. First, the groups in terms of the $\mathrm{P}$ associates $(\mathrm{Ca} / \mathrm{Mg}, \mathrm{K}, \mathrm{Fe} / \mathrm{Al})$ were selected subjectively to show the transition of the elements associated with $\mathrm{P}$ in the ash, depending 
on the molar ash-mixing and depending on the temperature. Furthermore, it was assumed that an individual group of phosphates shows a similar behavior when applied as fertilizer. An evaluation of the fertilization potential of the compounds in these groups has been done in previous publications [31, 32]. The chosen approach also neglects the role of the plant, the soil, and also the varying plant availability within one group [33]. Additionally, the assumption of equilibrium in the calculations gives a simplified picture of the potential $\mathrm{P}$ associations in the fuel blends. The shift from $\mathrm{Ca}, \mathrm{Fe}$, and $\mathrm{Al}$ phosphates towards $\mathrm{K}$ phosphates is assumed to occur without kinetic limitations as a solid-solid reaction or due to precipitation from the melt. In reality, the formation of $\mathrm{K}$ phosphates will probably be enhanced by volatilized or molten reaction agents, whereas solid-solid reaction might be inhibited significantly. Furthermore, the calculations suggest that $\mathrm{K}$ phosphates such as $\mathrm{KMgPO}_{4}$ are the most stable phosphate form in this system. Therefore, the only phosphates occurring in P-lean fuel blends are $\mathrm{K}$ phosphates or, at higher temperatures, molten phosphates. This equilibrium assumption proposes that several other stable phosphates, which may have formed previously in the SS ash due to the high content of $\mathrm{Ca}$ [34], e.g., $\mathrm{Ca}_{3}\left(\mathrm{PO}_{4}\right)_{2}$, would disintegrate to make $\mathrm{P}$ available for the reaction with excess $\mathrm{K}$. Considering the occurrence and stability of Ca phosphates, this is probably not always the case in practice.

The potential of $\mathrm{P}$ compounds precipitated from the molten ash fraction was identified in the equilibrium precipitation calculations. Mixtures with 60 mol.\% or more of agricultural ash produced melt that resulted in precipitated phosphates containing $\mathrm{K}$, which is an agreement with the overall chemical potential and the thermodynamic stability of these phosphates (see Fig. 3). Notably, the mixtures with 20 mol.\% agricultural residue ash (65 wt $\%$ WS in WSS, $76 \mathrm{wt} \% \mathrm{SH}$ in SSH) generated melt with higher potential for $\mathrm{K}$ phosphate formation than the average ash composition. This may occur due to higher tendencies of $\mathrm{K}$ and $\mathrm{P}$ to be incorporated in the melt than $\mathrm{Ca}$, resulting in higher $\mathrm{K} / \mathrm{Ca}$ ratios in the melt. Therefore, the formation of $\mathrm{K}-(\mathrm{Ca}, \mathrm{Mg})$ phosphates instead of $(\mathrm{Ca}, \mathrm{Mg})$ phosphates is thermodynamically favored. This effect is partially reduced when more than $50 \mathrm{~mol} . \%$ of the ash elements are incorporated in the melt due to the incorporation of additional $\mathrm{Ca}$. In summary, the results indicate that partial formation of melt could enhance the formation of K-bearing phosphates, since the chemical composition of the melt may be advantageous, and the kinetics may be enhanced in comparison with solid-solid reactions.

Although the calculations indicate that molten ashes of fuel blends may precipitate mainly as $\mathrm{K}$ phosphates, real precipitation cases might differ significantly. A major aspect that is lost in equilibrium cooling is the formation of amorphous material due to non-equilibrium phase transitions. Previous studies showed that amorphous material might represent a large fraction of condensed ash phases and the presence of other stable phosphates such as whitlockite $\left(\mathrm{Ca}_{3}\left(\mathrm{PO}_{4}\right)_{2}\right)$, hydroxyapatite $\left(\mathrm{Ca}_{5}\left(\mathrm{PO}_{4}\right)_{3} \mathrm{OH}\right)$, or tridymite polymorphs of aluminum phosphate $\left(\mathrm{AlPO}_{4}\right)$ has been shown previously and needs to be considered [11, 35].

\section{Conclusion}

Thermodynamic equilibrium calculations were performed to predict the ash transformation chemistry of sewage sludge mixtures with sunflower husks or wheat straw under combustion and gasification conditions. The low initial melting temperature of sewage sludge ash, dominated by $\mathrm{P}, \mathrm{Fe}, \mathrm{Si}, \mathrm{Ca}$, and $\mathrm{Al}$, increased significantly when the share of agricultural fuel was above $50 \mathrm{wt} \%$ (approx. $10 \mathrm{~mol} . \%$ in the ash). Wheat straw (Kand Si-rich) and sunflower husks (K-rich) showed significantly different melting behavior when mixed with sewage sludge for thermochemical conversion, which could be mainly attributed to the high shares of $\mathrm{Si}$ in wheat straw, forming large amounts of low-melting K silicate compounds at comparably low temperatures. The melting tendencies during gasification shifted towards lower temperatures for all fuel blends where sewage sludge ash was dominant. The appearance of melt at lower temperatures was found to coincide with the presence and stability of $\mathrm{Fe}^{2+}$ compounds, especially vivianite. $\mathrm{P}$ in sewage sludge ashes in the calculations was mostly associated with $\mathrm{Ca}, \mathrm{Fe}$, and $\mathrm{Al}$. When mixed with wheat straw or sunflower husks, the thermodynamic equilibrium shifted towards Kbearing and molten phosphates. The precipitation of molten ashes showed high stability of K-bearing phosphates formed through equilibrium cooling in the mixtures. Alteration of the $\mathrm{P}$ speciation by co-conversion of sewage sludge with agricultural residues towards potentially more plant available phosphates was thermodynamically favored due to the high stability of K-bearing phosphates. As this alteration is a desired outcome, the results may establish a basis for practical implementation in the future.

Funding information Open access funding provided by Luleå University of Technology. This study received financial support from the Swedish Research Council for Environment, Agricultural Sciences and Spatial Planning (Formas), project 942-2015-619, and from the Swedish Research Council, project 2016-04380. Additionally, N.S. received financial support from FORMAS Mobility grant no. 2017-01613.

Open Access This article is licensed under a Creative Commons Attribution 4.0 International License, which permits use, sharing, adaptation, distribution and reproduction in any medium or format, as long as you give appropriate credit to the original author(s) and the source, provide a link to the Creative Commons licence, and indicate if changes were made. The images or other third party material in this article are included in the article's Creative Commons licence, unless indicated otherwise in a credit line to the material. If material is not included in the article's Creative Commons licence and your intended use is not permitted by statutory regulation or exceeds the permitted use, you will need to obtain permission directly from the copyright holder. To view a copy of this licence, visit http://creativecommons.org/licenses/by/4.0/. 


\section{References}

1. Neset T-SS, Cordell D (2012) Global phosphorus scarcity: identifying synergies for a sustainable future. J Sci Food Agric 92:2-6. https://doi.org/10.1002/jsfa.4650

2. Ott C, Rechberger H (2012) The European phosphorus balance. Resour Conserv Recycl 60:159-172. https://doi.org/10.1016/j. resconrec.2011.12.007

3. Harrison EZ, Oakes SR, Hysell M, Hay A (2006) Organic chemicals in sewage sludges. Sci Total Environ 367:481-497. https://doi.org/10.1016/j.scitotenv.2006.04.002

4. Donatello S, Tyrer M, Cheeseman CR (2010) EU landfill waste acceptance criteria and EU Hazardous Waste Directive compliance testing of incinerated sewage sludge ash. Waste Manag 30:63-71. https://doi.org/10.1016/j.wasman.2009.09.028

5. Marani D, Braguglia CM, Mininni G, Maccioni F (2003) Behaviour of $\mathrm{Cd}, \mathrm{Cr}, \mathrm{Mn}, \mathrm{Ni}, \mathrm{Pb}$, and $\mathrm{Zn}$ in sewage sludge incineration by fluidised bed furnace. Waste Manag 23:117-124. https:// doi.org/10.1016/S0956-053X(02)00044-2

6. Liu J, Fu J, Ning X, Sun S, Wang Y, Xie W et al (2015) An experimental and thermodynamic equilibrium investigation of the $\mathrm{Pb}, \mathrm{Zn}$, $\mathrm{Cr}, \mathrm{Cu}, \mathrm{Mn}$ and $\mathrm{Ni}$ partitioning during sewage sludge incineration. $\mathrm{J}$ Environ Sci 35:43-54. https://doi.org/10.1016/j.jes.2015.01.027

7. Steckenmesser D, Vogel C, Böhm L, Heyde B, Adam C (2018) Fate of heavy metals and polycyclic aromatic hydrocarbons (PAH) in sewage sludge carbonisates and ashes - a risk assessment to a thermochemical phosphorus-recycling process. Waste Manag 78: 576-587. https://doi.org/10.1016/j.wasman.2018.06.027

8. Gorazda K, Tarko B, Wzorek Z, Kominko H, Nowak AK, Kulczycka J, Henclik A, Smol M (2017) Fertilisers production from ashes after sewage sludge combustion - a strategy towards sustainable development. Environ Res 154:171-180. https://doi. org/10.1016/j.envres.2017.01.002

9. Krüger O, Adam C (2015) Recovery potential of German sewage sludge ash. Waste Manag 45:400-406. https://doi.org/10.1016/j. wasman.2015.01.025

10. Shiba NC, Ntuli F (2017) Extraction and precipitation of phosphorus from sewage sludge. Waste Manag 60:191-200. https://doi.org/ 10.1016/j.wasman.2016.07.031

11. Nanzer S, Oberson A, Huthwelker T, Eggenberger U, Frossard E (2014) The molecular environment of phosphorus in sewage sludge ash: implications for bioavailability. J Environ Qual 43:1050-1060. https://doi.org/10.2134/jeq2013.05.0202

12. Stemann J, Peplinski B, Adam C (2015) Thermochemical treatment of sewage sludge ash with sodium salt additives for phosphorus fertilizer production - analysis of underlying chemical reactions. Waste Manag 45:385-390. https://doi.org/10.1016/j.wasman.2015.07.029

13. Li H, Han K, Wang Q, Lu C (2015) Influence of ammonium phosphates on gaseous potassium release and ash-forming characteristics during combustion of biomass. Energy Fuels 29:2555-2563. https://doi.org/10.1021/acs.energyfuels.5b00285

14. Grimm A, Skoglund N, Boström D, Boman C, Öhman M (2012) Influence of phosphorus on alkali distribution during combustion of logging residues and wheat straw in a bench-scale fluidized bed. Energy Fuels 26:3012-3023. https://doi.org/10.1021/ef300275e

15. Kumpiene J, Brännvall E, Wolters M, Skoglund N, Čirba S, Aksamitauskas VČ (2016) Phosphorus and cadmium availability in soil fertilized with biosolids and ashes. Chemosphere 151:124 132. https://doi.org/10.1016/j.chemosphere.2016.02.069

16. Xue Z, Zhong Z, Zhang B (2019) Experimental studies on cocombustion of sludge and wheat straw. Catalysts 9:182. https:// doi.org/10.3390/catal9020182
17. Zhao Y, Ren Q, Na Y (2018) Phosphorus transformation from municipal sewage sludge incineration with biomass: formation of apatite phosphorus with high bioavailability. Energy Fuels 32: 10951-10955. https://doi.org/10.1021/acs.energyfuels.8b01915

18. Krueger BC, Fowler GD, Templeton MR, Moya B (2020) Resource recovery and biochar characteristics from full-scale faecal sludge treatment and co-treatment with agricultural waste. Water Res 169: 115253. https://doi.org/10.1016/j.watres.2019.115253

19. Deng S, Tan H, Wang X, Yang F, Cao R, Wang Z, Ruan R (2017) Investigation on the fast co-pyrolysis of sewage sludge with biomass and the combustion reactivity of residual char. Bioresour Technol 239:302-310. https://doi.org/10.1016/j.biortech.2017.04.067

20. Bale CW, Bélisle E, Chartrand P, Decterov SA, Eriksson G, Hack K, Jung IH, Kang YB, Melançon J, Pelton AD, Robelin C, Petersen S (2009) FactSage thermochemical software and databases - recent developments. Calphad 33:295-311. https://doi.org/10.1016/j. calphad.2008.09.009

21. Arnout S, Nagels E (2016) Modelling thermal phosphorus recovery from sewage sludge ash. Calphad 55:26-31. https://doi.org/10. 1016/j.calphad.2016.06.008

22. Yazhenskikh E, Jantzen T, Hack K, Muller M (2019) A new multipurpose thermodynamic database for oxide systems. РАСПЛАВЫ:116-124. https://doi.org/10.1134/ S0235010619010237

23. Shao J, Lee DH, Yan R, Liu M, Wang X, Liang DT, White TJ, Chen H (2007) Agglomeration characteristics of sludge combustion in a bench-scale fluidized bed combustor. Energy Fuels 21:2608 2614. https://doi.org/10.1021/ef070004q

24. Wilfert P, Mandalidis A, Dugulan AI, Goubitz K, Korving L, Temmink H, Witkamp GJ, van Loosdrecht MCM (2016) Vivianite as an important iron phosphate precipitate in sewage treatment plants. Water Res 104:449-460. https://doi.org/10.1016/ j.watres.2016.08.032

25. Wilfert P, Dugulan AI, Goubitz K, Korving L, Witkamp GJ, Van Loosdrecht MCM (2018) Vivianite as the main phosphate mineral in digested sewage sludge and its role for phosphate recovery. Water Res 144:312-321. https://doi.org/10.1016/j.watres.2018.07. 020

26. Mac an Bhaird ST, Walsh E, Hemmingway P, Maglinao AL, Capareda SC, KP MD (2014) Analysis of bed agglomeration during gasification of wheat straw in a bubbling fluidised bed gasifier using mullite as bed material. Powder Technol 254:448-459. https://doi.org/10.1016/j.powtec.2014.01.049

27. Skoglund N, Umeå universitet, Tillämpad fysik och elektronik. Ash chemistry and fuel design focusing on combustion of phosphorusrich biomass. Department of applied physics and electronics, Umeå universitet, 2014

28. Anicic B, Lin W, Dam-Johansen K, Wu H (2018) Agglomeration mechanism in biomass fluidized bed combustion - reaction between potassium carbonate and silica sand. Fuel Process Technol 173:182-190. https://doi.org/10.1016/j.fuproc.2017.10.005

29. Wei X, Schnell U, Hein K (2005) Behaviour of gaseous chlorine and alkali metals during biomass thermal utilisation. Fuel 84:841848. https://doi.org/10.1016/j.fuel.2004.11.022

30. Boström D, Skoglund N, Grimm A, Boman C, Öhman M, Broström M, Backman R (2012) Ash Transformation chemistry during combustion of biomass. Energy Fuels 26:85-93. https:// doi.org/10.1021/ef201205b

31. Holm O, Thomé-Kozmiensky E, Quicker P, Kopp-Assenmacher S (eds) (2018) Verwertung von Klärschlamm. Thomé-Kozmiensky Verlag GmbH, Neuruppin

32. Steckenmesser D, Vogel C, Adam C, Steffens D (2017) Effect of various types of thermochemical processing of sewage sludges on 
phosphorus speciation, solubility, and fertilization performance. Waste Manag 62:194-203. https://doi.org/10.1016/j.wasman. 2017.02.019

33. Kratz S, Schick J, Øgaard AF (2016) P Solubility of inorganic and organic P sources. In: Schnug E, De Kok LJ (eds) Phosphorus Agric. 100 Zero. Springer Netherlands, Dordrecht, pp 127-154. https://doi.org/10.1007/978-94-017-7612-7_7

34. Chen J, Tang S, Yan F, Zhang Z (2020) Efficient recovery of phosphorus in sewage sludge through hydroxylapatite enhancement formation aided by calcium-based additives. Water Res 171:115450. https://doi.org/10.1016/j.watres.2019.115450

35. Lynn CJ, Dhir RK, Ghataora GS, West RP (2015) Sewage sludge ash characteristics and potential for use in concrete. Constr Build Mater 98:767-779. https://doi.org/10.1016/j.conbuildmat.2015.08. 122

Publisher's Note Springer Nature remains neutral with regard to jurisdictional claims in published maps and institutional affiliations. 